\title{
Could Covid-19 Worsen Food Insecurity in Burkina Faso?
}

\author{
Patrice Rélouendé Zidouemba ${ }^{1}$. Somlanare Romuald Kinda ${ }^{2}$. \\ Idrissa Mohamed Ouedraogo ${ }^{3}$
}

Accepted: 9 October 2020 / Published online: 26 October 2020

(c) European Association of Development Research and Training Institutes (EADI) 2020

\begin{abstract}
This paper analyses the impact of the Covid-19 pandemic on households' food security in Burkina Faso. For this purpose, we have made use of a single country's computable general equilibrium model and formulated two alternative scenarios (optimistic and pessimistic). While the baseline already shows a worrying food situation, our results suggest that the pandemic of Covid-19 contributes to a worsening of food security. First, the food deficit of poor rural and urban households worsens. Second, even if their food consumption decreases, the urban non-poor households seem to be resilient to the Covid-19 pandemic. The severity of food insecurity is increasing among poor households in rural and urban areas, whereas the non-poor rural households are likely to fall into the category of vulnerable people. Third, the negative impacts on food security can be explained by the combination of several factors such as a rise in food prices, a decrease in households' incomes and remittances. Finally, the negative impact on food security seems permanent, as the deviation from the baseline persists over 10 years (2020-2030).
\end{abstract}

Keywords COVID-19 · Food security · Computable general equilibrium

\section{Résumé}

Cet article analyse l'impact de la pandémie de la COVID-19 sur la sécurité alimentaire des ménages au Burkina Faso. À cette fin, nous avons utilisé un modèle d'équilibre général calculable mono-pays et formulé deux scénarios alternatifs (l'un

Somlanare Romuald Kinda kindaromuald@gmail.com

Patrice Rélouendé Zidouemba patrice.zidouemba@gmail.com

Idrissa Mohamed Ouedraogo

Idriss_mo@yahoo.fr

1 Université Nazi Boni, Bobo-Dioulasso, Burkina Faso

2 Université Thomas Sankara, Ouagadougou, Burkina Faso

3 Université Aube Nouvelle, Forge Afrique, Ouagadougou, Burkina Faso 
optimiste, l'autre pessimiste). Alors que la situation de référence montre déjà une situation alimentaire préoccupante, nos résultats suggèrent que la pandémie de COVID-19 contribue à une aggravation de l'insécurité alimentaire. Premièrement, le déficit alimentaire des ménages pauvres ruraux et urbains s'aggrave. Deuxièmement, même si leur consommation alimentaire diminue, les ménages urbains non pauvres semblent faire preuve de résilience face à la pandémie de COVID-19. La gravité de l'insécurité alimentaire augmente parmi les ménages pauvres des zones rurales et urbaines, tandis que les ménages ruraux non pauvres sont susceptibles de tomber dans la catégorie des personnes vulnérables. Troisièmement, l'impact négatif sur la sécurité alimentaire peut s'expliquer par la combinaison de plusieurs facteurs tels qu'une hausse des prix des denrées alimentaires, une diminution des revenus des ménages et une diminution des envois de fonds. Enfin, l'impact négatif sur la sécurité alimentaire semble permanent, puisque l'écart par rapport au scénario de référence persiste sur 10 ans (2020-2030).

JEL Classification C68 $\cdot$ I15 $\cdot$ Q18

\section{Introduction}

After a prolonged decline from 2005 to 2014, several reports (FAO et al. 2020; FSIN 2020) highlight a sharp spike in hunger across the World. Reports show that the number of undernourished people in the World rose from 628.9 million (8.6\%) to 687.8 million (8.9\%) between 2014 and 2019.

Evidence suggests that the situation is alarming in Sub-Saharan Africa. In 2019, more than 234.7 million (around 22\%) suffered from chronic food deprivation. In addition, the number of undernourished people is on the rise in all sub-regions of Sub-Saharan Africa especially in West Africa. According to the 2020 Global Report on Food Crises (FSIN 2020), five (5) of the ten (10) worst food crises in the World occurred in Sub-Saharan Africa in 2019. In other words, more than half (54.07\%) of the affected people in the World live in Sub-Sahara African countries. These trends can be explained by several factors such as institutional quality (Rossignoli and Balestri 2018), conflicts (Dabalen and Paul 2014; George et al. 2020), climatic events (Zidouemba 2017; Kinda and Badolo 2019), and economic factors (trade openness (Dithmer and Abdulai 2017), Foreign Direct Investments (Mihalache-O'keef and Li 2011), economic growth (Harttgen et al. 2013)).

Since December 2019, the world has been facing a health crisis linked to the coronavirus (Covid-19) outbreak. It has spread from China to the developed and developing countries. Although African countries being among the last ones to be affected, they are facing a collective threat to human life, social cohesion, and an economic disaster. These countries are characterized by a very inefficient health system and by fragile institutions. Several reports (ECA 2020; IMF 2020; World Bank 2020) conclude that the spread of the coronavirus will seriously dampen African economies. According to the United Nation's Economic Commission for Africa (ECA 2020), the continent's economic growth rate could contract sharply. The 
reports by the International Monetary Fund (IMF 2020) and the World Bank (World Bank 2020) anticipate an economic recession ranging from -2.1 to $-5.1 \%$ mainly due to the negative impact of the pandemic on the world trade and its impact on African economies.

Beyond its economic impact, the Covid-19 pandemic can reduce food security in the World especially in Sub-Saharan Africa. According to several reports such as the Global Report on Food Crises (FSIN 2020), the Covid-19 pandemic may contribute to food insecurity and crises. Indeed, to curb the spread of the coronavirus (Covid-19), several countries have adopted measures such as closure of the air, land and rail borders, the shutdown of schools and universities, production units and services (markets, taverns, urban and interurban transport services). These measures can impede the functioning of the agricultural sector and disrupt food supply chain at the global level. In addition, they can deteriorate livelihoods especially in fragile countries and more specifically for people working in the agricultural and/or the informal sector. The FSIN (2020) has concluded that the Covid-19 pandemic could additionally increase the number of undernourished people in the World by 83 million in the optimistic scenario, and by 132 million in the pessimistic scenario in $2020 .^{1}$

According to several reports (The Food Crisis Prevention Network 2020a), West Africa is currently affected by a major food crisis which has impacted around 11.4 million. The combined effects of a high insecurity and the spread of the pandemic of Covid-19 can contribute to push 17 million into a food and nutrition insecurity in the region.

On 16, June 2020, more than 78, 333 of individuals were affected by the Coronavirus disease (Covid-19) in West Africa, including 959 confirmed cases in Burkina Faso, making this country one of the least affected in the region. To contain the spread of the Covid-19, Burkina Faso's authorities have prompted and quickly adopted several measures, including the closure of the air, land and rail borders, the shutdown of schools and universities, production units and services (markets, drinking places, urban and interurban transport services), the ban on gatherings of more than 50 people, etc. While they aim at limiting the spread of the virus, these measures can undoubtedly have important effects on all sectors of the economy (economic growth, employment), and households' livelihoods, especially food access for the most vulnerable people in both rural and urban regions.

In Burkina Faso, the Covid-19 pandemic could contribute to exacerbating food insecurity for two reasons. Firstly, agricultural production and food security are highly dependent on weather shocks (Tankari 2020). According to The Food Crisis Prevention Network (2020b), rainfall variability has reduced agricultural production between 6 and $15 \%$ in 2019. This could tip $10.1 \%$ of population into food insecurity. In addition, over the past 5 years, the country is affected by violent terrorist attacks and regional unrest. The Fund for Peace (2020) has concluded that Burkina Faso is

\footnotetext{
1 Without the Covid-19 pandemic, the number of undernourished people in the World is projected at 695.7 million in 2020 . With the Covid-19 pandemic, it could increase by 778.3 million in the optimistic scenario and 827.9 million in the pessimist scenario.
} 
rated as the fourth most affected country in 2019. This has led to the closure of more than 2000 schools, 600,000 internally displaced people and shutdown of health centres. These recurrent and violent attacks have deteriorated households' livelihoods in several regions (FAO 2020).

This recurrent insecurity and climate vulnerability partly explain the persistence of the food and nutrition crisis. In December 2019, the proportion of the population that experienced acute global malnutrition was between 4.8 and $11.7 \%$.

This paper's objective is to analyse the impacts of the Covid-19 on households' food security in Burkina Faso. It contributes to the economic literature in two ways. On the one hand, while previous papers investigating the macroeconomic effects of pandemics have been widely applied to developed countries (Smith et al. 2009; Dixon et al. 2010; Keogh-Brown et al. 2010; Verikios et al. 2012; Prager et al. 2017), this paper focuses on a developing country which is Burkina Faso. On the other hand, it contributes to the newly produced literature on the economic effects of Covid-19 (Atkeson 2020; Suryahadi et al. 2020; Atkeson 2020; Suryahadi et al. 2020; Arouna et al. 2020; Martin et al. 2020; Nicola et al. 2020; Kinda et al. 2020).

For this study, we use a single country's computable general equilibrium model and data representing the structure of Burkina Faso's economy (a social accounting matrix). The model's main advantage is its ability to adequately represent sectoral and institutional linkages, as well as trade relations between Burkina Faso and the rest of the world. This methodological framework is fundamental insofar as the effects of the pandemic may not only affect the national economy but the world economy as well.

The underlying hypotheses of this paper are both the time needed to stamp out the pandemic followed by a resumption of economic activities on the one hand, and to the impact on remittances from the diaspora and exports on the other hand.

Given uncertainty during the pandemic, two alternative hypotheses (scenarios) have been formulated: (i) an optimistic scenario which assumes that the pandemic will be under control at the end of 2020, while remittances from the diaspora and world demand for Burkina Faso's products will contract by $10 \%$; and (ii) a pessimistic scenario stating that the pandemic extends beyond end-2020 with a $20 \%$ drop in world demand for Burkina Faso's exports and remittances from the diaspora.

The rest of the paper is structured as follows: After presenting the methodological framework and simulations ("Methodology" section), we present the results ("Empirical Results" section) and research limitations ("Research Limitations" section) before concluding and providing policy recommendations ("Conclusion and Policy Recommendations" section).

\section{Methodology}

Several authors have analysed the economic impact of pandemics. Some of them have used macroeconomic single-sector models (Fan 2003; Jonung and Roeger 2006) while others apply a multi-sector computable general equilibrium approach (Smith et al. 2009; Dixon et al. 2010; Keogh-Brown et al. 2010; Verikios et al. 2012; Prager et al. 2017). The former have the advantage of using quarterly models, which 


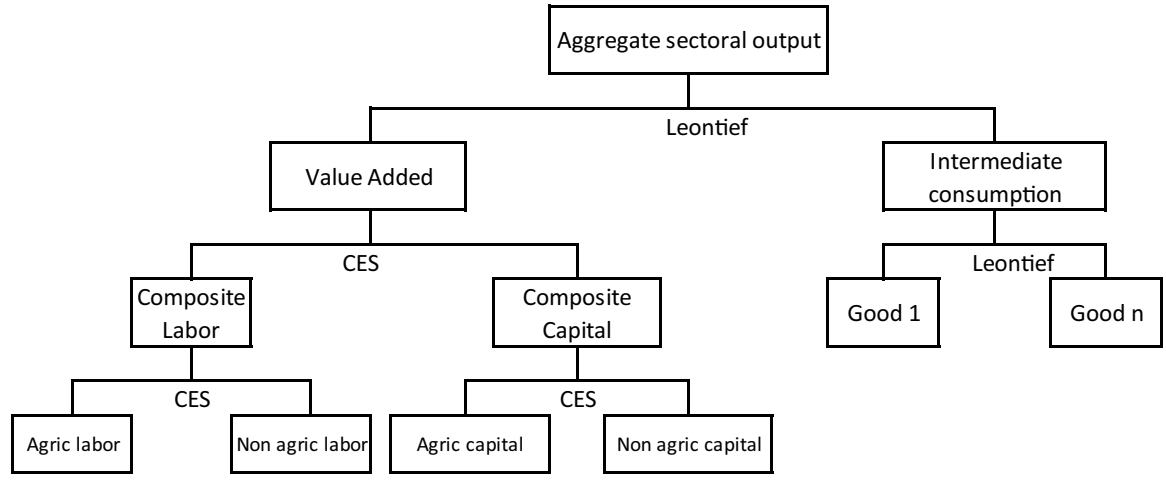

Fig. 1 The structure of the production function

allows them to take into account the short nature of pandemics. However, they present the disadvantage of having a single-sectoral approach which can ignore some sectors particularly relevant for the study of the economic effects of pandemics. The latter apply models which have the advantage of taking into account all sectors of the economy, but which have the disadvantages of having an annual periodicity and therefore are not able to accurately capture the short nature of the pandemics (Verikios et al. 2012). To analyse the impact of the Covid-19 pandemic on food security, we use a Computable General Equilibrium (CGE) model, as many sectors are potentially affected. Furthermore, from the perspective of food security study, the CGE approach is particularly suited (Zidouemba 2014). Indeed, it can adequately represent simultaneously the micro-economic consumer behaviour and income generation at the household level, and equilibria at the macroeconomic level. The spillover effects linked to the change in a given sector's activity, the direct impacts (on the markets of goods and services) and indirect impacts (through markets of the production factors) are represented, making it possible to analyse the conditions of poverty reduction and progress or not in food security.

\section{The Model}

\section{Main Features}

The CGE model used in this study is based on PEP-1-t developed by Decaluwé et al. (2010). Businesses are assumed to operate in perfect competition by maximizing profits/minimizing costs given their production technology constraint and the prices of goods, services and factors (price-taking behaviour). The production technology is determined by a nested structure (Fig. 1). At the top level, a Leontief function combines intermediate consumption and value added to determine the sectoral output. At the second level, sectoral value added is obtained by a Constant Elasticity of Substitution (CES) function that aggregates a composite labour and a composite capital. At the bottom level, on the side of value added, a CES function combines various labour categories to give the composite labour on the one hand, and various capital categories to 
give the composite capital. Finally, on the side of intermediate consumption at the second level, various goods and services are combined by a Leontief function to determine the intermediate consumption. It should be noted that PEP-1-t allows a firm to produce more than one good or service. In that case, the aggregate output of the corresponding firm is determined by a Constant Elasticity of Transformation (CET) function of various outputs.

Domestic demand for commodities, whether imported or produced domestically, consists of household demand, investment, public administrations demand, intermediate demand and demand for trade margins. Producers are assumed to allocate output to market outlets to maximize sales revenue. Aggregate output is allocated among exports and domestic sales thanks to a CET function. The representative buyer's behaviour is symmetrical to the representative producer's behaviour, as it is assumed that local products are imperfect substitutes for imports (heterogeneous goods hypothesis represented by a CES aggregator function).

Households receive their income from production factors (labour and capital) and transfers from other institutions. After tax payments and transfers to other institutions, the disposal income is affected to goods and services consumption according to a Linear Expenditure System function derived from the maximization of a Stone-Geary utility function.

\section{Special Treatments for a Better Study of Food Security}

Some features have been introduced to allow a better representation of Burkina Faso's economy. First, an imperfect mobility of the capital, rather than an initial sectoral capital fixity, is modelled making it possible, with the intersectoral labour mobility, the necessary adjustments in terms of sectoral reallocation of production factors following a shock in order to optimize production.

Therefore, three macro sectors are defined (agriculture, industry and services). The capital mobility is imperfect in the sense that agricultural capital can be used alternatively for rice or maize subsectors, for example. However, agricultural capital cannot migrate to non-agricultural subsectors like metals industry. Similarly, industrial capital can migrate between industrial subsectors but not to agriculture or to services. The closure of the capital market is modified accordingly. The conditions of capital market equilibrium now arise at the macrosectoral level:

$$
\begin{array}{ll}
\text { in the agricultural sector: } & \sum_{j 1} K S_{k, j 1, t}=\sum_{j} K D_{k, j 1, t} \\
\text { in the industry sector: } & \sum_{j 2} K S_{k, j 2, t}=\sum_{j} K D_{k, j 2, t} \\
\text { in the services sector: } \quad \sum_{j 3} K S_{k, j 3, t}=\sum_{j} K D_{k, j 3, t},
\end{array}
$$


where $K S$ and $K D$ represent the supply and demand of capital, respectively; $j_{1}, j_{2}$ and $j_{3}$ are the subsets of agriculture, industry and services, respectively. These three equations determine the rental rates $R_{\mathrm{k}, \mathrm{agsec}, \mathrm{t}}$ of capital at the macrosectoral level.

The allocation of the new capital across sectors follows a modified version of Jung and Thorbecke (2003) investment demand specification. In this specification, the volume of new capital is allocated to each sector in proportion to the existing capital stock, and this proportion varies according to the ratio between the rental rate and the user cost of the capital. Thus, an increase in this ratio in a given sector (resulting either from an increase in the rental rate or from a decrease in the user cost of capital) tends to increase the share of new capital in that sector.

Second, unemployment is represented and set at $23 \%$ in the baseline, which corresponds to the unemployment rate in 2015 (INSD 2016). The equilibrium in the labour market is achieved by variation in labour quantities, while nominal wages are fixed. A decrease in sectoral activities can then translate into a decrease in the volume of employment, which implies an increase in unemployment. Second, households are divided into four groups to isolate those that are food insecure. The two groups classified as poor, both in rural and urban areas, will be at the heart of the analysis to focus on vulnerable populations.

Third, for the analysis of food security, we have opted to introduce a module which makes it possible to estimate the quantities of food products consumed per capita per year. These quantities consumed are then compared to the standards established by the Permanent Inter-State Committee for Drought Control in the Sahel (CILSS). Indeed, the CILSS (2004) has proposed consumption standards by country, considering the habits and diversification of food consumption. This approach offers a much finer analysis of the food situation than in the usual approaches where one analyses the percentage of changes in consumption for a representative household without taking into account nutritional qualities or an absolute gap to a threshold (Zidouemba and Gerard 2018).

\section{Macro-Closure}

Closure rules are particularly important as they are one of the main drivers of the results. Three important closure rules are assumed in the model: the private account closure, the government account closure and external account closure.

The private account closure assumption concerns the savings-investment balance. The type of PEP-1-t model we are using is Neo-Classical. The marginal propensity to save is constant such that variation in income leads to variation in savings, which brings variations in investment. Therefore, investment is "savings driven".

The government or public account closure is about the way public balance is affected by the shock. Many assumptions could be made. Here we assume that real government expenditures are exogenous and public savings adjust effects. This means that when facing a negative shock with increasing public deficits, we will have a crowding out effect with private investment.

The last closure rule and probably the most important for our simulations, concerns the external account (current account balance). This is particularly important when trade flows are likely to change significantly in the wake of the shock 
simulated. In the model, we assume that the Current account balance is fixed, and the real exchange rate is adjusted to maintain this exogenous level. This approach which is conservative has two main justifications. First any variation in the top of the Balance of payment (CAB) will be compensated by an equivalent variation in the bottom (financial) part. Yet, PEP-1-t model does not model this component, so a good strategy is to keep it exogenous. Second, not fixing the CAB can yield high misleading results, particularly in terms of welfare and food security changes. Indeed, with an endogenous $\mathrm{CAB}$, the country can increase substantially its imports through foreign savings without any limit while with the exogenous $\mathrm{CAB}$ specification, any increase in imports must be financed by an increase in exports. This is made possible through the flexible real exchange rate. Therefore, a proper (unbiased) food security analysis can be done.

\section{Data and Calibration}

\section{Social Accounting Matrix and Parameters}

The model has been calibrated to a 2013 Social Accounting Matrix (SAM) focused on the agricultural sector. The SAM has been built by the Ministry of Agriculture and Hydro-agricultural Development. It contains 213 accounts divided into 67 economic activities (including 30 agricultural activities, 23 manufacturing activities, 14 services), 129 tradable goods accounts; 03 categories of labour distinguished according to qualification (Family labour, paid agricultural labour and non-agricultural labour); 02 capital accounts (agricultural capital and non-agricultural capital), 05 tax accounts (direct, indirect, sales, labour and imports), 04 representative household categories (poor and non-poor in rural and urban areas); one margin account, a savings-investment account, 01 account of firms, 01 government account and 01 account of the rest of the world.

The range of (free) parameters used in the model comes from the literature (Annabi et al. 2006). The values of the main parameters are given in Table 1.

\section{The Measure of Food Security}

As mentioned above, an effort has been made to convert the values (in millions of CFA francs) of food consumption of the social accounting matrix into volume (kilogram per capita per year), based on data on populations by household category (Zida and Kambou 2014) and average prices of each food item (SONAGESS 2015) (Table 2). Converting the values of food consumption from the SAM into Kilogram per capita per year has several advantages. First, it is possible to have a more precise vision of the real nutritional state of individuals. Then, this makes it possible to verify that the SAM data on food consumption are consistent with human consumption standards. Finally, the analysis of food security is enriched by considering both variations in food consumption and the deviation from food consumption standards. For instance, an economic policy that would lead to a $20 \%$ increase in the consumption of cereals by the poor may appear to be 
Table 1 Value of main parameters of the model

\begin{tabular}{|c|c|c|c|c|c|}
\hline \multicolumn{2}{|c|}{ Income elasticity } & \multirow{2}{*}{$\begin{array}{l}\text { Armington } \\
\text { elasticity }\end{array}$} & \multirow{2}{*}{$\begin{array}{l}\text { CET elasticity (exports } \\
\text { and domestic sales) }\end{array}$} & \multirow{2}{*}{$\begin{array}{l}\text { Elasticity of substitution for } \\
\text { primary factors (value added) }\end{array}$} & \multirow{2}{*}{$\begin{array}{l}\text { Frisch } \\
\text { parameter }\end{array}$} \\
\hline $\begin{array}{l}\text { Agri- } \\
\text { cultural } \\
\text { goods }\end{array}$ & $\begin{array}{l}\text { Other } \\
\text { goods }\end{array}$ & & & & \\
\hline 0.5 & 1.5 & 3.5 & 2 & 1.5 & -3.5 \\
\hline
\end{tabular}

a remarkably effective policy for food security. However, if this increase does not help to reach the cereal consumption standard because of a large initial gap from the norm, this policy will not be considered highly effective in achieving food security.

Unfortunately, the approach of per capita food consumption does not consider either the micronutrient content of the consumed food or the distribution of food consumption within the household among gender and age. This might have implications for food security in the longer term as it would affect the food production. Moreover, the decline in food consumption is likely to have longer terms of effects on labour productivity as child malnutrition might be significantly higher.

\section{The COVID-19 Scenarios}

Two alternative hypotheses (scenarios) have been formulated: (i) an optimistic scenario which assumes that the pandemic will be under control by the end of 2020, while remittances from the diaspora and world demand for Burkina Faso's products will contract by $10 \%$; and (ii) a pessimistic scenario stating that the pandemic extends beyond end-2020 with a $20 \%$ drop in world demand for Burkina Faso's exports and remittances from the diaspora.

At the national level, the measures adopted by the authorities to contain the spread of the Covid-19 could lead to a reduction in production capacity in the production sectors. According to the West African Economic and Monetary Union Report (WAEMU 2020), all economic sectors have been negatively affected. More interestingly, the Service sector would be the most impacted followed by the Industry and Agriculture. If the agricultural sector seems to be the least affected in the short term, experts expect greater effects in the coming months due to the unavailability of agricultural inputs.

Additional arguments from national experts and resource persons conclude that the relaxing measures against the spread of Covid-19 have allowed national firms to be able to adapt to this situation by taking measures (rotation system, reduction of staff) to ensure the continuity of activities. Therefore, the reduction in the productive capacities of the sectors would be less than $15 \%$.

Because of this uncertainty, two alternative hypotheses (scenarios) have been formulated. The optimistic scenario (COVID1) assumes a reduction in the productive capacities of the non-agricultural sector (Industry and services) by 5\% and the 
Table 2 The baseline food consumption

\begin{tabular}{|c|c|c|c|c|c|}
\hline & Rural poor & Urban poor & Rural non-poor & Urban non-poor & $\begin{array}{l}\text { Average } \\
\text { prices (CFA/ } \\
\mathrm{kg})\end{array}$ \\
\hline Population & 5699365 & 887597 & 5135930 & 2293754 & \\
\hline \multicolumn{6}{|c|}{$\begin{array}{l}\text { Consumption (values } \\
\text { of the SAM in } \\
\text { millions of CFA } \\
\text { francs) }\end{array}$} \\
\hline Grain & 180538.36 & 25207.60 & 220463.75 & 94004.03 & 194 \\
\hline Legumes & 6726.68 & 816.73 & 8102.06 & 3700.70 & 150 \\
\hline Tubers & 4451.29 & 590.41 & 5830.28 & 4875.53 & 160 \\
\hline Vegetables & 24160.40 & 4739.70 & 30709.56 & 15539.17 & 300 \\
\hline Fruits & 7552.47 & 1174.43 & 13695.02 & 7415.07 & 300 \\
\hline Sugar & 10097.48 & 1295.02 & 16230.85 & 8762.97 & 500 \\
\hline Vegetable oil & 24785.43 & 6280.24 & 45037.05 & 24542.95 & 500 \\
\hline Meat & 48972.49 & 7637.40 & 76218.80 & 55246.19 & 1000 \\
\hline milk & 30989.71 & 3805.85 & 57227.47 & 34370.28 & 500 \\
\hline Fish & 5820.62 & 1598.76 & 9326.15 & 15162.77 & 750 \\
\hline Eggs & 6961.20 & 472.54 & 19944.08 & 12788.32 & 1500 \\
\hline \multicolumn{6}{|c|}{$\begin{array}{l}\text { Food consump- } \\
\text { tion expenditures } \\
\text { converted into kg/ } \\
\text { capita/year }\end{array}$} \\
\hline Grain & 163.28 & 146.39 & 221.27 & 211.25 & \\
\hline Legumes & 7.87 & 6.13 & 10.52 & 10.76 & \\
\hline Tubers & 4.88 & 4.16 & 7.09 & 13.28 & \\
\hline Vegetables & 14.13 & 17.80 & 19.93 & 22.58 & \\
\hline Fruits & 4.42 & 4.41 & 8.89 & 10.78 & \\
\hline Sugar & 3.54 & 2.92 & 6.32 & 7.64 & \\
\hline Vegetable oil & 8.70 & 14.15 & 17.54 & 21.40 & \\
\hline Meat & 8.59 & 8.60 & 14.84 & 24.09 & \\
\hline Milk & 10.87 & 8.58 & 22.29 & 29.97 & \\
\hline Fish & 1.36 & 2.40 & 2.42 & 8.81 & \\
\hline Eggs & 0.81 & 0.35 & 2.59 & 3.72 & \\
\hline
\end{tabular}

Source 2013 Social Accounting Matrix

agricultural sector by $4 \%$, respectively. In the pessimistic scenario (COVID2), the reduction in the productive capacities of agricultural and non-agricultural sectors would be $10 \%$.

At the international level, the Covid-19 pandemic could also lead to both a contraction in world demand for Burkina Faso's exports and remittances from the Diaspora. The hypothesis of a drop in world demand for Burkina Faso's exports is justified by the fact that the decline in growth (or even recession) in the world economy, will lead to a reduction in the purchasing power of foreign consumers. 
Based on recent available data (INSD 2020), Burkina Faso's total export has increased by $24.4 \%$ from 2019 (semester 1) and 2020 (semester 1). This result can be explained by a huge increase in mining exports by $39.7 \%$ (due to an exceptional increase in gold price) and a decrease of other export products (cotton, etc.) by $10.14 \%$. Even if the contribution of mining in total export is important, it has been excluded from export shocks. Indeed, mining sector is capital intensive sector. More than $85 \%$ of households' livelihoods depend on agricultural activities. We assume that a negative shock on other export products will negatively impact the households' food security. We assume that the world demand for Burkina Faso's exports will be reduced by around $10 \%$ in the optimistic scenario and by $20 \%$ in the pessimistic scenario, respectively (Table 3).

Similarly, some studies have shown that the diaspora remittances could drop by 23.1\% for Sub-Saharan Africa (Bisong et al. 2020). Taking into account the hypothesis of remittances for Households' livelihoods is important. Indeed, Kalantaryan and McMahon (2020) have shown that the decline in remittances from the diaspora caused by the Covid-19 pandemic could greatly negatively affect the most vulnerable households in Sub-Saharan Africa. They have also pointed out that countries with the highest scores of dependences on remittances from the diaspora are simultaneously characterized by highest economic vulnerability and financial exclusion. These are Niger, Burkina Faso, and Mali, respectively. In Burkina Faso, households depending on remittances from the diaspora have no internet access on their phones (72\%), and do not have a bank account (7\%). Therefore, the spread of Covid-19 and the measures adopted would further reduce their ability to receive these incomes from the diaspora. We assume that remittances from the diaspora will be reduced by around $10 \%$ in the optimistic scenario and by $20 \%$ in the pessimistic scenario, respectively.

\section{Empirical Results}

\section{The Baseline Food Consumption}

The poor people's food consumption as described by the 2013 social accounting matrix is largely below the standards established by the CILSS for almost all food items (Table 4). Unlike the poor, the non-poor have consumption levels far above these standards. The deficit is particularly significant among the urban poor for the most food items (grain, legumes, tubers, sugar, milk and eggs). This worrying food situation for the poor is the result of low incomes. Indeed, while the national poverty line income is estimated at 153530 FCFA in 2013 (INSD 2015), the urban poor's incomes (rural poor) are on average $49.08 \%(27.50 \%)$ below this threshold (Fig. 2). The large deviation from the poverty line income, leading to a strong gap of consumption from the CILSS standards illustrates a great vulnerability of poor households to an even small economic shock.

For our analysis, we mainly focus on three food groups (grains, fruits and vegetables, and animal products (meat and fish). According to the Ministry of 
Table 3 Summary of the scenarios

\begin{tabular}{cccclll}
\hline & \multicolumn{2}{l}{ Shock in production capacity in } & & \multicolumn{2}{l}{ Shock in } \\
\cline { 2 - 3 } \cline { 5 - 6 } & Agriculture (\%) & Industry (\%) & Services (\%) & $\begin{array}{l}\text { Exports } \\
\text { demand (\%) }\end{array}$ & Remittances (\%) \\
\hline $\begin{array}{c}\text { Optimistic } \\
\text { scenario } \\
(\text { COVID1) }\end{array}$ & -4 & -5 & -5 & -10 & -10 \\
$\begin{array}{c}\text { Pessimistic } \\
\text { scenario } \\
(\text { COVID2) }\end{array}$ & -10 & -10 & -10 & & -20 & -20 \\
\hline
\end{tabular}

Shock to production capacity reflects a direct shock to sectoral productivity

Agriculture and Hydro-agricultural Development (MAAH 2010), these three food groups enable to have a precise vision of the food situation of Burkina Faso's households. Indeed, they provide more than $80 \%$ of carbohydrate intakes, $70 \%$ of energy intakes, $42 \%$ of lipid intakes and $32 \%$ of protein intakes.

\section{Impacts on Food Consumption}

Figure 3 shows that the COVID-19 scenarios reduce households' food consumption. The food deficit of poor households worsens. Indeed, for poor rural households, the deviation from the CILSS cereal consumption standard goes from - 19.56 to $-25.39 \%$ in the optimistic scenario (COVID1) and to $-30.85 \%$ in the pessimistic scenario (COVID2). For urban poor, the grain consumption deficit which was $-27.89 \%$ in the baseline, reaches $-33.16 \%$ in the optimistic scenario and - $38.13 \%$ in the pessimistic scenario. The non-poor households in rural and urban areas, despite their grain consumption level above the CILSS standard (baseline), are also expected to have a significant drop in consumption. For the rural non-poor, the grain consumption always reaches the threshold in the optimistic scenario but falls below the threshold in the pessimistic scenario. Regarding the urban poor, they experience grain consumption below the threshold from the optimistic scenario. As the category of non-poor households is quite heterogeneous (one finds both households which are slightly above the poverty line and wealthy households which are largely above the line), the drop in average consumption below the CILSS standard means that a large share of rural and urban non-poor households falls into the poor household category following the COVID-19 shock.

The consumption of fruits and vegetables also falls due to the COVID-19 crisis (Fig. 4). There is indeed an increase in the consumption deficit of these products both for the rural poor, going from $-28.66 \%$ (BAU) to $-34.05 \%$ (COVID1) and $-39.15 \%$ (COVID2) and for the urban poor declining from $-14.58 \%$ (BAU) to $-20.76 \%$ (COVID1) and - 26.63\% (COVID2). While the urban non-poor manage to maintain a level of consumption above the threshold in the two scenarios simulated, the rural non-poor observe a drop in the level of consumption which is slightly below the CILSS standard in the pessimistic scenario (COVID2). 
Table 4 The deviation of food consumption from the CILSS standards in the baseline

\begin{tabular}{|c|c|c|c|c|c|}
\hline & \multirow{2}{*}{$\begin{array}{l}\text { Standards of } \\
\text { the CILSS }\end{array}$} & \multicolumn{4}{|c|}{ Gap from the CILSS standards (\%) } \\
\hline & & Rural poor & Urban poor & Rural non-poor & Urban non-poor \\
\hline Grain & 203 & -19.56 & -27.89 & 9.00 & 4.06 \\
\hline Legumes & 7 & 12.40 & -12.37 & 50.24 & 53.66 \\
\hline Tubers & 6 & -18.64 & -30.71 & 18.25 & 121.41 \\
\hline Vegetables & 20 & -29.35 & -11.00 & -0.34 & 12.91 \\
\hline Fruits & 6 & -26.38 & -26.49 & 48.14 & 79.60 \\
\hline Sugar & 4 & -11.42 & -27.05 & 58.01 & 91.02 \\
\hline Vegetable oil & 14 & -37.87 & 1.08 & 25.27 & 52.86 \\
\hline Meat & 12 & -28.39 & -28.30 & 23.67 & 100.71 \\
\hline Milk & 18 & -39.58 & -52.36 & 23.81 & 66.49 \\
\hline Fish & 2 & -31.91 & 20.08 & 21.06 & 340.70 \\
\hline Eggs & 1 & -18.57 & -64.51 & 158.88 & 271.69 \\
\hline
\end{tabular}

Source the CGE model simulations

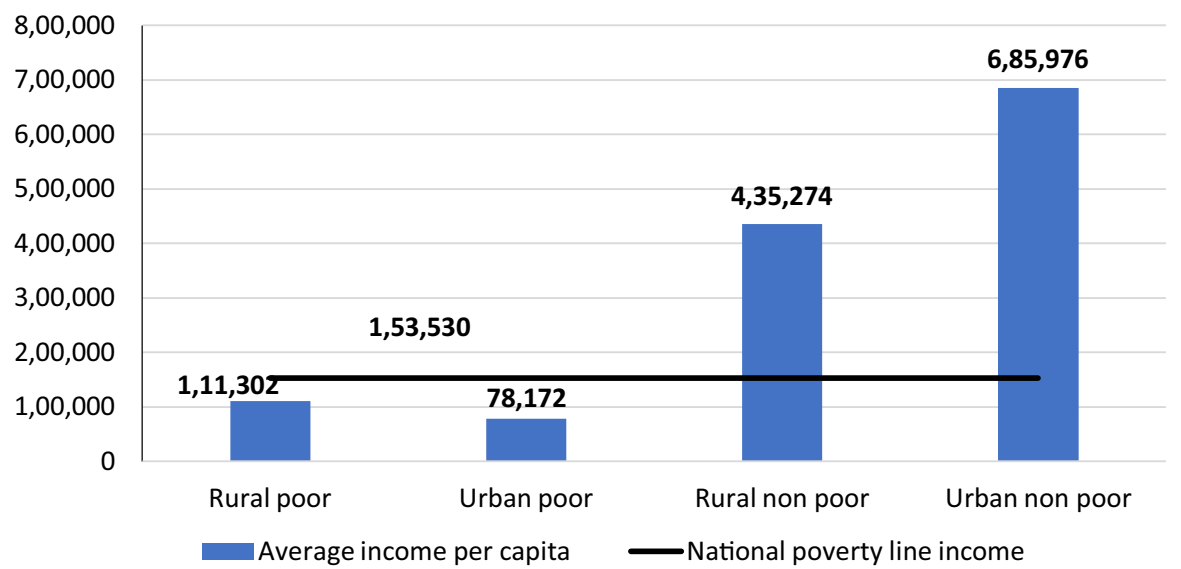

Fig. 2 Average annual income per capita in the baseline (CFA francs). Source the CGE model simulations

Regarding the consumption of animal products (meat and fish), the deficit is also widening for poor households (Fig. 5). While the consumption by non-poor urban dwellers, although falling, remains largely above the consumption standard for animal products, consumption by non-poor rural dwellers, which was slightly above the CILSS standard, barely crosses the threshold in the pessimistic scenario (COVID2). Thereby, the severity of food insecurity is increasing among poor households in rural areas as well as in urban areas, and an important share of non-poor rural people is likely to fall into the category of vulnerable people. 


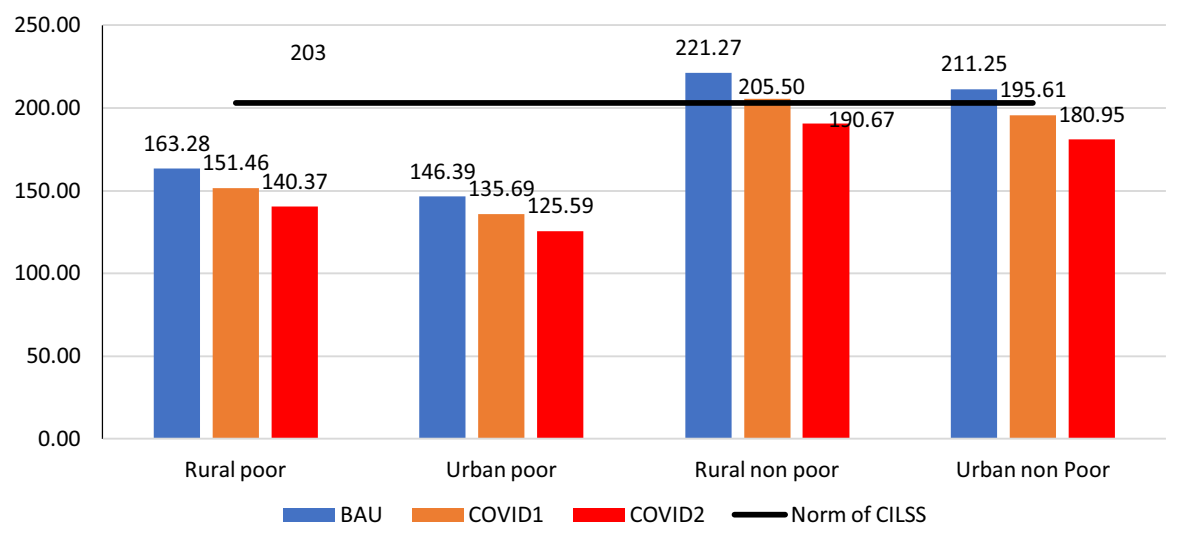

Fig. 3 Impact on grain consumption (kg/capita/year). Source the CGE model simulations

The negative impacts on food security stem from two essential mechanisms. We have both an increase in food prices (Table 5) and a decrease in nominal incomes (Fig. 6).

The rise in food prices varies between products but is around $4 \%$ in the optimistic scenario and $8 \%$ in the pessimistic scenario. This is the result of a sharp drop in sectoral production because of the pandemic. While production drops in average by $4 \%$ for grains, fruits and vegetables, and animal products in the optimistic scenario (COVID1), this drop reaches $9 \%$ in the pessimistic scenario (COVID2). This increase in prices is reinforced by the difficulties linked to international trade, as the fall in production is hardly offset by an increase in imports following trade restrictions in the pandemic context.

The fall in the sectoral production results in an increase in unemployment (5.62\% in the optimistic scenario and $10.94 \%$ in the pessimistic scenario). The increase in unemployment and the decrease in remittances lead to a drop in nominal incomes (ranging from -1.56 and $-3.16 \%$ for the rural poor and from -1.47 and $-3.05 \%$ for the urban poor). Thus, the fall in nominal incomes, associated with the rise in prices leads to a sharp fall in real incomes and explains the very unfavourable impacts on food security of the poor both in rural and urban areas.

\section{Macroeconomic Impacts}

At the macroeconomic level (Figs. 7, 8), the COVID-19 crisis could result in a significant drop in the economic growth rate in the optimistic scenario $(2.50 \%$ against a forecast growth of $6.5 \%$ for 2020$)$ and an economic recession $(-0.87 \%)$ in the pessimistic scenario.

The fall in economic activity will generate a drop in public revenue (between 2.87 and $5.83 \%$ ), which could lead to a larger public deficit that increases by $6.13 \%$ in the optimistic scenario, and by $13.45 \%$ in the pessimistic scenario. 


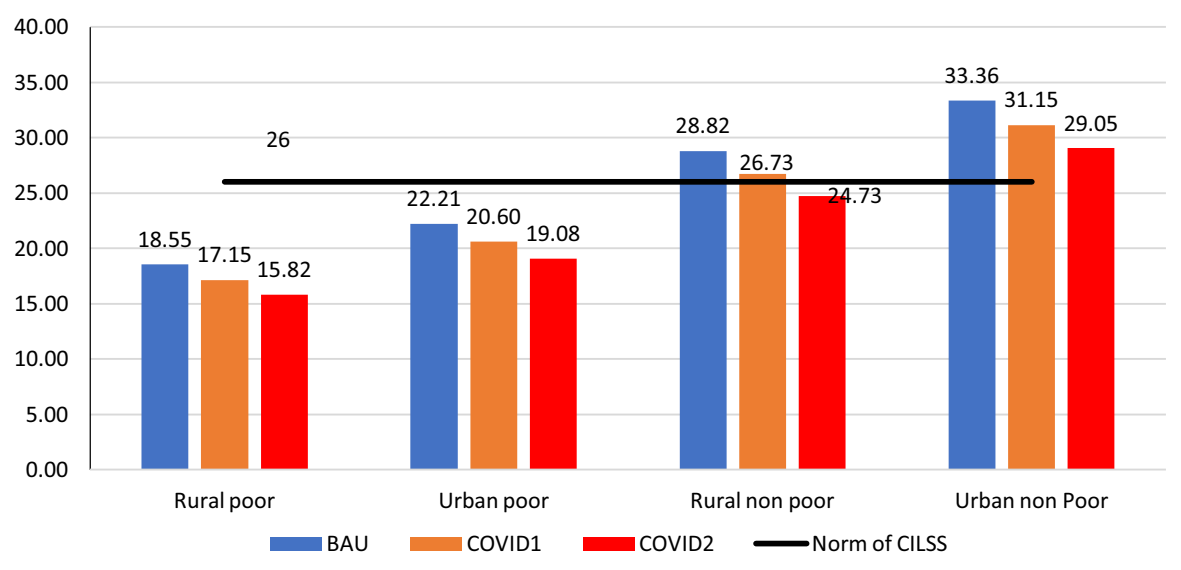

Fig. 4 Impact on fruits and vegetables consumption (kg/capita/year). Source the CGE model simulations

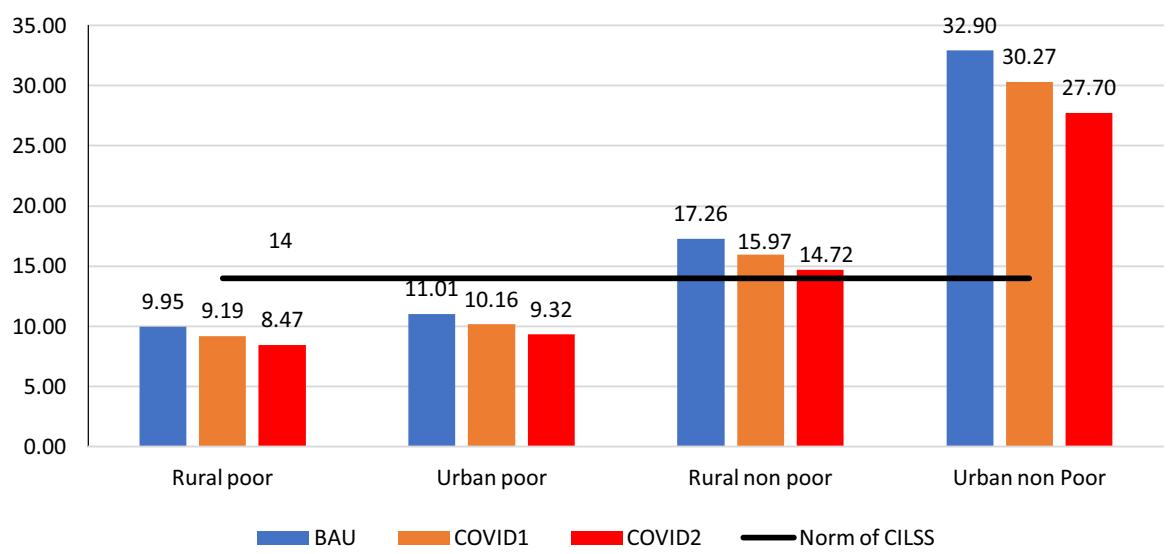

Fig. 5 Impact on meat and fish consumption (kg/capita/year). Source: the CGE model simulations

The contraction of domestic supply of the production sectors, as well as the international trade restriction due to the protectionist policies adopted by the developed and emerging countries, will likely cause a surge in consumer prices. Indeed, the results show that the consumer price index increases by $5.3 \%$ in the optimistic scenario and by $7.40 \%$ in the pessimistic scenario.

Finally, as mentioned earlier above, the contraction of the sectoral production could lead to an increase in unemployment (between +5.62 and $+10.94 \%$ ) as some companies will be forced to release a significant part of their employees to survive the crisis. Admittedly, the formal and especially informal private service sectors are major providers of jobs in Burkina Faso. 
Table 5 The impacts on food production and consumer prices

\begin{tabular}{lllllr}
\hline & \multicolumn{2}{l}{ Food production } & & \multicolumn{2}{l}{ Consumer prices } \\
\cline { 2 - 3 } & COVID1 & COVID2 & & COVID1 & COVID1 \\
\hline Grain & -4.33 & -8.43 & & 3.64 & 7.44 \\
Legumes & -4.55 & -8.91 & & 5.12 & 10.73 \\
Tubers & -4.20 & -8.24 & 4.77 & 9.89 \\
Vegetables & -3.78 & -7.14 & & 3.79 & 7.79 \\
Fruits & -5.35 & -10.63 & & 3.53 & 7.60 \\
Vegetable oil & -5.42 & -10.43 & & 1.33 & 2.30 \\
Meat & -3.48 & -6.80 & & 3.49 & 7.15 \\
Milk & -5.92 & -11.61 & & 3.87 & 8.28 \\
Fish & -5.00 & -10.00 & & 3.73 & 8.30 \\
Eggs & -5.00 & -9.99 & 6.07 & 13.63 \\
\hline
\end{tabular}

Source the CGE model simulations

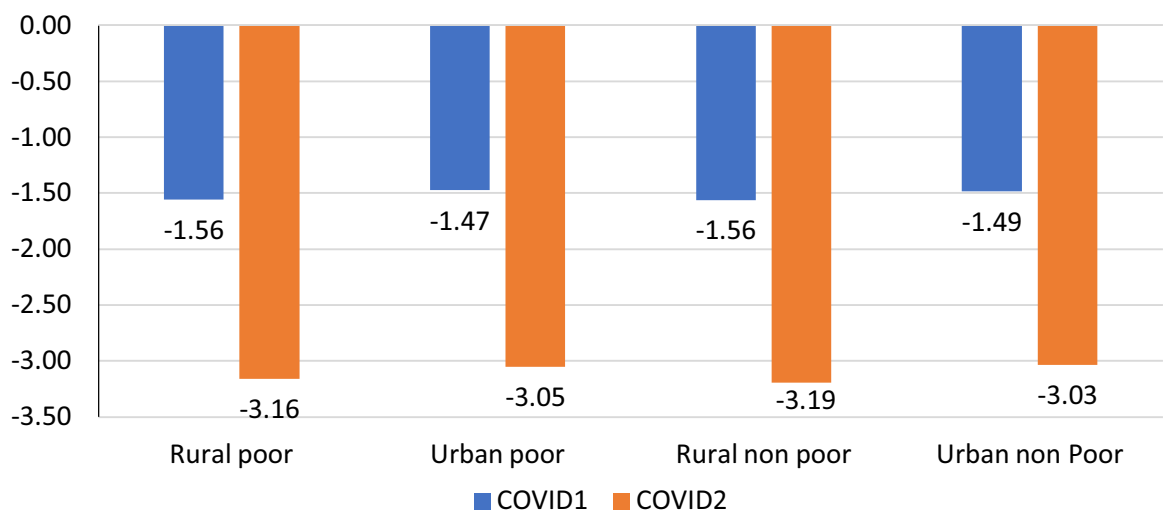

Fig. 6 Impact on nominal incomes (in percentage). Source the CGE model simulations

\section{Sensitivity Tests}

The behavioural parameters (Table 1) used for the implementation of the model stemmed from other sources. Since these parameters are not specific to Burkina Faso, it is important to perform a sensitivity test to see if our results are or not very sensitive to the parameters used. We present the impacts on Food consumption when dividing these parameters by 1.5 and then multiplying them by 1.5 , respectively. Table 6 shows the results of the food consumption sensitivity test. We run the pessimistic scenario by considering different values of the exogenous parameters. The middle column gives the same results as those in Figs. 3, 4 and 5. It can be seen that the food consumption levels do not differ significantly with the value of the parameters as the deviations from the initial values are always less than $3 \%$. 


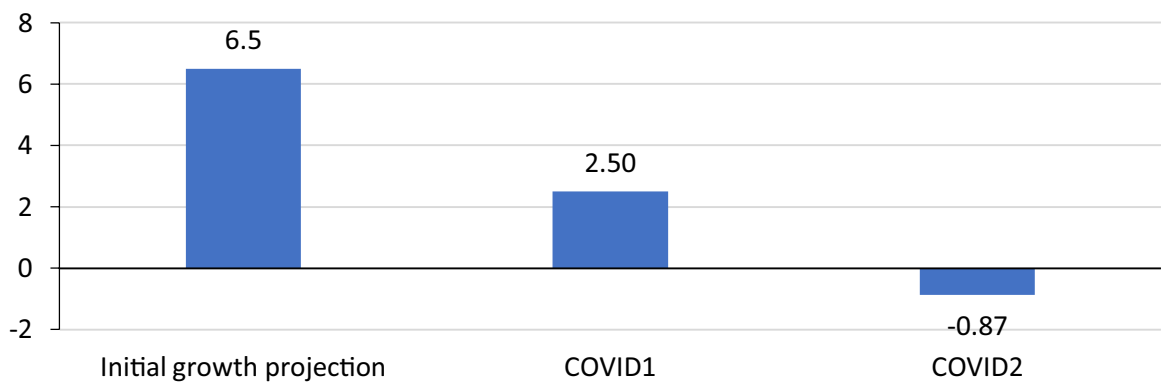

Fig. 7 Impact on GDP growth. Source the CGE model simulations

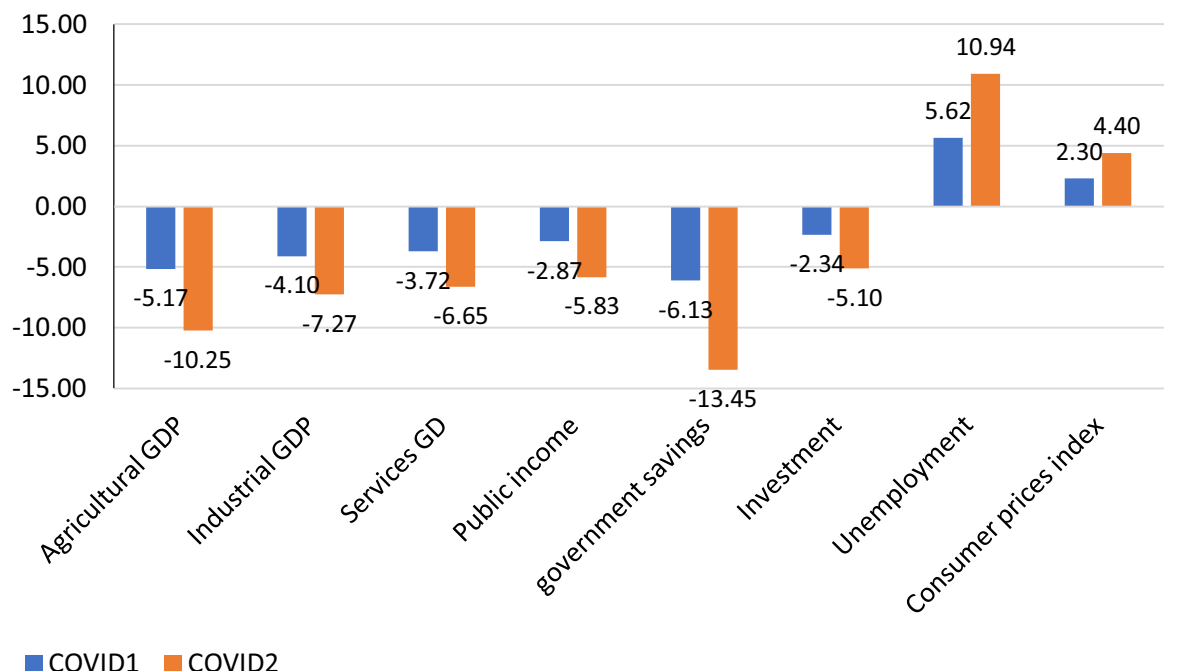

Fig. 8 Macroeconomic impacts (\%). Source the CGE model simulations

\section{Long-Term Effect of the COVID-19}

As highlighted in the World Bank report on the effects of the pandemic (World Bank 2020), it is possible that COVID-19 will have permanent effects in the long term. To investigate these dynamic effects, we run the simulations in dynamics over the period 2020-2030. Our estimates presented in Fig. 9 suggest that real GDP would be $3.9 \%$ lower than in the baseline scenario in 2020 in the optimistic scenario. This deviation increases slightly to $4.39 \%$ in 2025 and $4.82 \%$ in 2030 . The same observation can be done with cereal consumption both in optimistic scenario and pessimistic scenario. This finding indicates that if adequate measures aiming to quickly address human capital destruction and disruptions of public infrastructure caused by 
Table 6 Changes of food consumption in COVID2 scenario with different exogenous parameters values

\begin{tabular}{lccc}
\hline & Parameters/1.5 & Parameters & Parameters $* 1.5$ \\
\hline Grain consumption & & & \\
Rural poor & 138.57 & 140.37 & 141.38 \\
Urban poor & 123.54 & 125.59 & 126.95 \\
Rural non-poor & 187.94 & 190.67 & 192.25 \\
Urban non-poor & 177.88 & 180.95 & 182.89 \\
Fruits and vegetables consumption & & & \\
Rural poor & 15.63 & 15.82 & 15.95 \\
Urban poor & 18.80 & 19.08 & 19.28 \\
Rural non-poor & 24.42 & 24.73 & 24.96 \\
Urban non-poor & 28.70 & 29.05 & 29.33 \\
Meat and fish consumption & & & \\
Rural poor & 8.64 & 8.47 & 8.28 \\
Urban poor & 9.53 & 9.32 & 9.09 \\
Rural non-poor & 15.01 & 14.72 & 14.41 \\
Urban non-poor & 28.36 & 27.70 & 26.92 \\
\hline
\end{tabular}

COVID-19 are not implemented, the long-term decline in productivity would lead to a permanent decline in both economic Growth and food security.

\section{Research Limitations}

The results discussed in this paper are derived from a model that does not pretend to represent all the complex relationships of Burkina Faso's economy and its diversity. However, it represents with appropriate orders of magnitude the main characteristics of the production and consumption system and reproduces the food situation observed for poor households.

Although we have been able to distinguish households according to their poverty situation, a finer disaggregation of the representative households by income quintile or even by income decile would have enabled to take into account the diversity of households classified here as poor in both rural and urban areas.

Likewise, computing food consumption levels based on the SAM, the population data by household category and average prices provide a stylized view of the food situation but remains approximate. The weakness of the statistical system in poor countries like Burkina Faso makes it difficult to draw solid conclusions about households' consumption levels. For example, there are difficulties in accurately assessing transfers between households, in the form of festivities or donations, since surveys are often based on expenditure. It is therefore possible that the initial consumption levels may be underestimated.

The COVID-19 has led to an increase in public spending in caring for people suffering from the disease. At the same time, terrorism which continues to gain ground and the current floods, reflections of climate change (the government of Burkina 


\section{0}

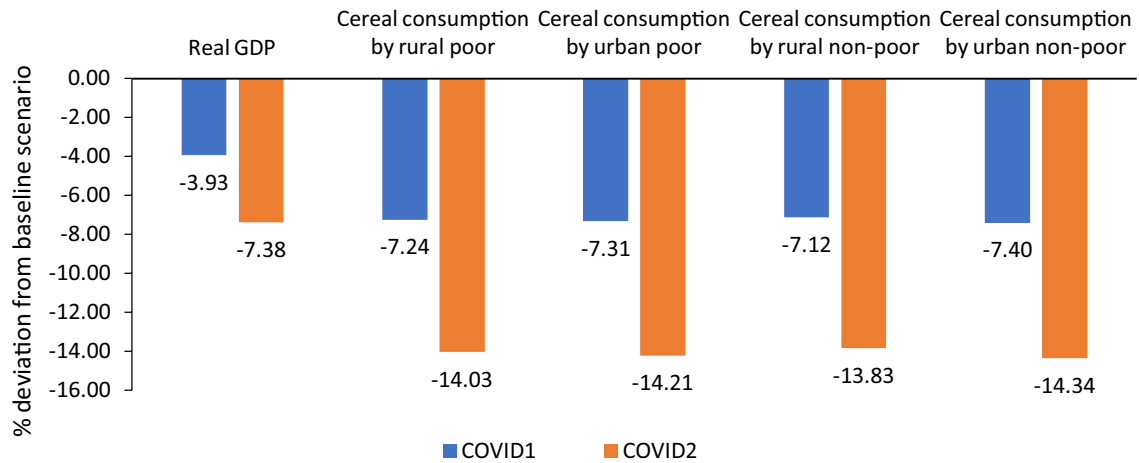

2025

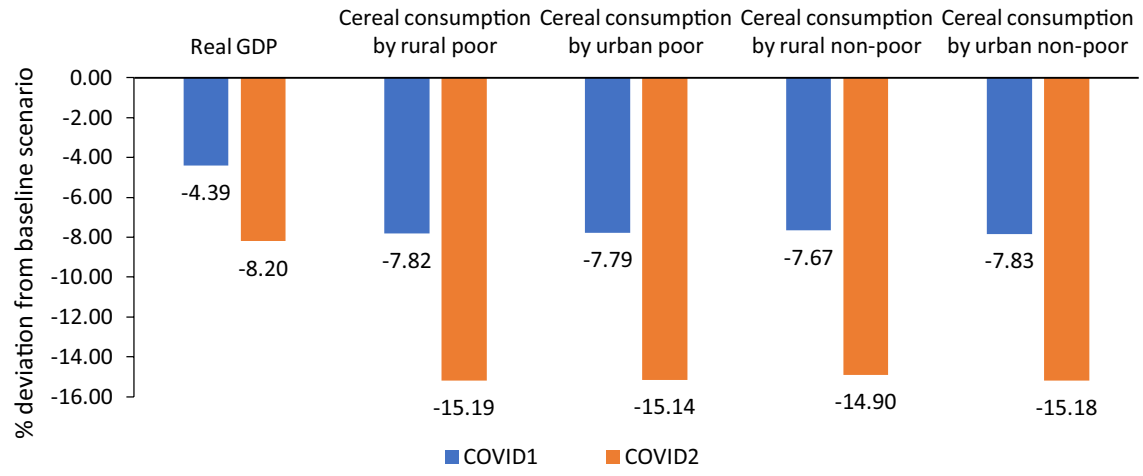

2030

Cereal Cereal Cereal Cereal consumption by consumption by consumption by consumption by

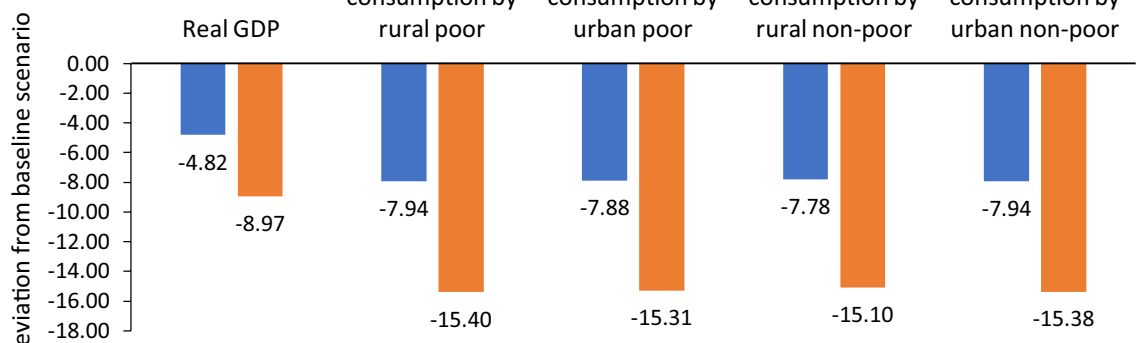

—COVID1 COVID2

Fig. 9 Long-Term Effect of COVID-19 in Burkina Faso.n Source the CGE model simulations 
Faso has just declared a state of natural disaster) requires an increase in public spending to address these issues. There is therefore an interaction between the current pandemic, terrorist conflicts, and climate change, which may exacerbate food insecurity. Unfortunately, the data currently available did not allow us to model this interaction. The results on food security may be more severe in the longer run than that which is presented in this paper.

\section{Conclusion and Policy Recommendations}

Although being among the last ones to be affected, African countries are facing a collective threat to human life, social cohesion, and an economic disaster. Indeed, beyond the health effects, the Covid-19 pandemic is likely to have severe economic and social impacts. The lockdown measures taken by most countries to curb its spread have had negative effects on domestic production activities and the external financial resources on which they are dependent for their economic development.

This paper analyses the impacts of the Covid-19 pandemic on households' food security in Burkina Faso. A computable general equilibrium model developed by Decaluwé et al. (2010) is adapted to Burkina Faso's economy and a 2013 social accounting matrix is used. In addition, to better evaluate food security, we have used the consumption of food products not in value, but in volume (kilogram per capita) and compared with consumption standards established for Burkina Faso by the Permanent Interstates Committee for Drought Control in the Sahel (CILSS). Given uncertainty over the duration of the pandemic, two alternative hypotheses (scenarios) have been formulated: (i) an optimistic scenario which assumes that the pandemic will be under control by the end of 2020, while remittances from the diaspora and world demand for Burkina Faso's products will contract by $10 \%$; and (ii) a pessimistic scenario propounding that the pandemic extends beyond end-2020 with a $20 \%$ drop in world demand for Burkina Faso's exports and remittances from the diaspora.

While the baseline already shows a worrying food situation, results indicate that the Covid-19 pandemic contributes to a worsening of food security. Firstly, the food deficit of poor households worsens. Indeed, for poor rural and urban households, the deviation from the CILSS's cereal consumption standard increases in the optimistic scenario (COVID1) and to $-30.85 \%$ in the pessimistic scenario (COVID2). Secondly, even if their food consumption decreases, the urban non-poor households seem to be resilient to the Covid-19 pandemic. In other words, the severity of food insecurity is increasing among poor households in rural areas as well as in urban areas, whereas the non-poor rural people are likely to fall into the category of vulnerable people.

Thirdly, the negative impacts on food security can be explained by the combination of several factors such as a rise in food prices (between 4 and 8\%) and a decrease in households' incomes (between -1.47 and -3.19\%).

Finally, at the macroeconomic level, economic growth could drop from $5.7 \%$ in 2019 to a range between +2.50 and $-1.87 \%$ in 2020 . The fall in economic activity will generate a drop in public revenue (between 2.87 and 5.83\%), which could 
lead to a larger public deficit increasing by $6.13 \%$ in the optimistic scenario, and by $13.45 \%$ in the pessimistic scenario. The contraction of the economic activity could also lead to an increase in unemployment (between +5.62 and $+10.94 \%$ ).

Our results are important in terms of recommendations. At the national level, they call for measures to mitigate the negative impacts on households. Thus, the government with the help of the international community should step up emergency response programs and social safety nets. In the short term, emergency response programs can include an increase in the number of beneficiaries of lean food assistance, coupling of cash transfers (by using mobile money) to the distribution of water, hygiene and sanitation kits and the rehabilitation of water points. In the medium term, the covid-19 pandemic can be an opportunity for the authorities to implement bold policy decisions for efficient social safety nets. Indeed, according to Vandeninden et al. (2019), the country's expenditure on social safety nets has increased from $0.3 \%$ of GDP to $2.32 \%^{2}$ between 2005 and 2015 . This rate is higher than other African countries' expenditures. However, they are essentially oriented to the fourth richest quintile. By reducing energy subsidies for instance, the government would realign existing expenditures on social safety nets on the poorest quantile (the most vulnerable households). This could contribute to opening fiscal space for additional investments (renewable energy, scholarships for the poorest, etc.). In addition, public authorities should adopt the appropriate measures to restore the national economy. For this purpose, financial supports and economic stimulus measures such as tax wavers and exemptions should be provided to companies and sectors (which are job providers) that are the most affected.

At the regional level and in conjunction with other West African countries, Burkina Faso should not only maintain the free movement of foodstuffs and agricultural inputs but also fight against obstructive customs procedures. In addition, they should ensure that health controls related to Covid-19 at the borders and seaports will not create more red tape in import procedures and disrupt food distribution chains.

Acknowledgements The authors acknowledge the infrastructure and support of the Centre de Formation d'Orientation et de Recherche pour la Gouvernance Economique en Afrique (FORGE Afrique). In addition, they would like to thank the editor, the reviewers for the constructive suggestions and Arouna Sanan for his editing service.

\section{References}

Annabi, N., J. Cockburn, and B. Decaluwé. 2006. Functional forms and parametrization of CGE models. MPIA working paper 2006-04.

Arouna, Aminou, Guillaume Soullier, Patricio del Villar Mendez, and Matty Demont. 2020. Policy options for mitigating impacts of COVID-19 on domestic rice value chains and food security in West Africa'. Global Food Security 26: 100405. https://doi.org/10.1016/j.gfs.2020.100405.

Atkeson, A. 2020. What will be the economic impact of COVID-19 in the US? Rough estimates of disease scenarios. Working paper series, no. 26867. Cambridge: National Bureau of Economic Research.

Bisong, A., P.E. Ahairwe, and E. Njoroge. 2020. The impact of COVID-19 on remittances for development in Africa. Maastricht: European Centre for Development Policy Management.

\footnotetext{
${ }^{2}$ African countries (transition economies) spend about $1.3 \%$ (1.5\%) of GDP on social safety nets respectively.
} 
Comité Permanent Inter-Etats de Lutte contre la Sécheresse dans le Sahel (CILSS). 2004. Normes de consommation des principaux produits alimentaires dans les pays du CILSS.

Dabalen, A.L., and S. Paul. 2014. Effect of conflict on dietary diversity: Evidence from Côte d'Ivoire. World Development 58: 143-158.

Decaluwé, B., A. Lemelin, V. Robichaud, and H. Maisonnave. 2010. PEP-1-t. Standard PEP model: Single-country, recursive dynamic version. Québec: Politique Économique et Pauvreté/Poverty and Economic Policy Network, Université Laval.

Dithmer, J., and A. Abdulai. 2017. Does trade openness contribute to food security? A dynamic panel analysis. Food Policy 69: 218-230.

Dixon, P.B., B. Lee, T. Muehlenbeck, M.T. Rimmer, A. Rose, and G. Verikios. 2010. Effects on the U.S. of an H1N1 epidemic: Analysis with a quarterly CGE model. Journal of Homeland Security and Emergency Management 7 (1): 1-17.

ECA. 2020. Trade policies for Africa to tackle Covid-19. Addis Ababa: Africa Trade Policy Centre.

Fan, E.X. 2003. SARS: Economic impacts and implications (1655-5260). ERD Policy Brief of Asian Development Bank 15: 1-10.

FAO, Ifad, UNICEF, WFP, \& WHO. 2020. The State of Food Security and Nutrition in the World 2020: Transforming food systems for affordable healthy diets. Paris: FAO.

FSIN. 2020. 2020 Global report on food crises: Joint analysis for better decisions. Saskatoon: FSIN.

George, J., A. Adelaja, and D. Weatherspoon. 2020. Armed conflicts and food insecurity: Evidence from Boko Haram's attacks. American Journal of Agricultural Economics 102 (1): 114-131.

Harttgen, K., S. Klasen, and S. Vollmer. 2013. Economic growth and child undernutrition in sub-Saharan Africa. Population and Development Review 39 (3): 397-412.

IMF. 2020. World economic outlook: The great lockdown. Washington, DC: IMF.

INSD. 2015. Profil de pauvreté et d'inégalités. In Résultats de l'enquête multisectorielle continue (EMC)phase 1. Ouagadouga: Institut National des Statistiques et de la Démographie.

INSD. 2016. Enquête nationale sur l'emploi et le secteur informel (ENESI-2015), thème 5: Chômage. Ouagadouga: INSD.

INSD. 2020. Note trimestrielle sur les statistiques du commerce extérieur: Deuxième trimestre 2020. Ouagadouga: INSD.

Jonung, L., and W. Roeger. 2006. The macroeconomic effects of a pandemic in Europe-A model-based assessment. Brussels: European Commission.

Jung, H.-S., and E. Thorbecke. 2003. The impact of public education expenditure on human capital, growth, and poverty in Tanzania and Zambia: A general equilibrium approach. Journal of Policy Modeling 25 (8): 701-725.

Kalantaryan, S., and S. McMahon. 2020. Covid-19 and remittances in Africa. Luxembourg: European Union.

Keogh-Brown, M.R., R.D. Smith, J.W. Edmunds, and P. Beutels. 2010. The macroeconomic impact of pandemic influenza: estimates from models of the United Kingdom, France, Belgium and The Netherlands. The European Journal of Health Economics 11 (6): 543-554.

Kinda, S.R., and F. Badolo. 2019. Does rainfall variability matter for food security in developing countries? Cogent Economics \& Finance 7 (1): 1640098.

Kinda, Romuald S., Patrice R. Zidouemba, and Idrissa M. Ouedraogo. 2020. How could the Covid-19 pandemic impact the economy of Burkina Faso? Economics Bulletin 40 (3): 2034-2046.

MAAH. 2010. Etude sur la dynamique de la consomation alimentaire au Burkina Faso. https://fsg.afre. msu.edu/srai/Bukina\%20Rapport\%20Consom\%20Final.pdf.

Martin, Amory, Maryia Markhvida, Stéphane. Hallegatte, and Brian Walsh. 2020. 'Socio-economic impacts of COVID-19 on household consumption and poverty. Economics of Disasters and Climate Change. https://doi.org/10.1007/s41885-020-00070-3.

Mihalache-O'keef, A., and Q. Li. 2011. Modernization vs. dependency revisited: Effects of foreign direct investment on food security in less developed countries. International Studies Quarterly 55 (1): 71-93. 
Nicola, Maria, Zaid Alsafi, Catrin Sohrabi, Ahmed Kerwan, Ahmed Al-Jabir, Christos Iosifidis, Maliha Agha, and Riaz Agha. 2020. The socio-economic implications of the coronavirus pandemic (COVID-19): A review. International Journal of Surgery 78 (June): 185-193.

Prager, F., D. Wei, and A. Rose. 2017. Total economic consequences of an influenza outbreak in the United States. Risk Analysis 37 (1): 4-19.

Rossignoli, D., and S. Balestri. 2018. Food security and democracy: Do inclusive institutions matter? Canadian Journal of Development Studies 39 (2): 215-233.

Smith, R.D., M.R. Keogh-Brown, T. Barnett, and J. Tait. 2009. The economy-wide impact of pandemic influenza on the UK: A computable general equilibrium modelling experiment. BMJ 339: b4571.

SONAGESS. 2015. Annuaire des prix des produits agricoles 2014. Ouagadougou: SONAGESS.

Suryahadi, A., R.A. Izzati, and D. Suryadarma. 2020. Estimating the impact of COVID-19 outbreak on poverty. Bulletin of Indonesian Economic Studies 56 (2): 175-192.

Tankari, M.R. 2020. Rainfall variability and farm households' food insecurity in Burkina Faso: Nonfarm activities as a coping strategy. Food Security 12 (3): 567-578.

The Food Crisis Prevention Network. 2020a. Food and nutrition crisis 2020. https://www.food-security. net/en/topic/food-and-nutrition-crisis-2020/.

The Food Crisis Prevention Network. 2020b. Food and nutrition situation/Burkina Faso. https://www. food-security.net/en/datas/burkina-faso/.

The Fund for Peace. 2020. Fragile States Index 2020_Annual report. Washington, DC: The Fund for Peace.

Vandeninden, F., R. Grun, and A. Semlali. 2019. The way forward for social safety nets in Burkina Faso. https://elibrary.worldbank.orghttps://doi.org/10.1596/32329.

Verikios, G., J.M. McCaw, J. McVernon, and A.H. Harris. 2012. H1N1 influenza and the Australian macroeconomy. Journal of the Asia Pacific Economy 17 (1): 22-51.

WAEMU. 2020. Rapport Covid-19, Impact de la Pandemie du Covid 19 sur le secteur Privé de l'UEMOA. https://www.uemoa.int/sites/default/files/bibliotheque/rapport_final_etude_impact_covid -19_ccr-uemoa.pdf.

World Bank. 2020. Africa Pulse. Washington, DC: World Bank.

Zida, Y., and S. Kambou. 2014. Cartographie de la Pauvreté et des Inégalites au Burkina Faso. Ouagadougou.

Zidouemba, P.R. 2014. Sécurité alimentaire, productivité agricole et investissements publics au Burkina Faso : une analyse à l'aide d'un modèle d'Équilibre Général Calculable dynamique et stochastique. (PhD). CIRAD - Montpellier SupAgro, UMR 1110 MOISA, Montpellier, France. https://prodinra. inra.fr/record/286982.

Zidouemba, P.R. 2017. Economy-wide implications of climate change in Burkina Faso. Economics Bulletin 37 (4): 2797-2808.

Zidouemba, P.R., and F. Gerard. 2018. Does agricultural productivity actually matter for food security in a landlocked sub-Saharan African Country? The case of Burkina Faso. Canadian Journal of Agricultural Economics/Revue canadienne d'agroeconomie 66 (1): 103-142.

Publisher's Note Springer Nature remains neutral with regard to jurisdictional claims in published maps and institutional affiliations. 